\title{
EKSPLORASI DAN UJI SENYAWA BIOAKTIF BAKTERI AGENSIA HAYATI UNTUK PENGENDALIAN PENYAKIT KRESEK PADA PADI
}

\author{
Sri Kurniawati ${ }^{1}$, Kikin Hamzah Mutaqin ${ }^{2}, \&$ Giyanto $^{2}$ \\ ${ }^{1}$ BPTP Banten, Badan Penelitian dan Pengembangan Kementerian Pertanian \\ Jl. Raya Ciptayasa Km 01 Ciruas, Serang-Banten \\ ${ }^{2}$ Laboratorium Bakteriologi Tumbuhan, Departemen Proteksi Tanaman, Fakultas Pertanian, Insitut Pertanian Bogor \\ Jl. Kamper, Kampus IPB Dramaga, Bogor 16680 \\ E-mail: giyanto2@yahoo.com
}

\begin{abstract}
Exploration of bacterial biocontrol agent and its potential bioactive compound to control rice bacterial leaf blight. The research aims were to obtain bacterial isolates which were potential as biological control agent of $X$. oryzae pv. oryzae, the causal agent of rice bacterial blight and to assess the effectiveness of their bioactive compounds, and to identify of the potential isolates. The research steps included bacterial isolation, screening based on antibiosis activity and pathogenicity test, characterization based on chitinolytic enzyme production, siderophores, and phosphate dissolution test, effectiveness test of bioactive compounds and molecular identification of potential isolates. Out of 156 bacterial isolates from rice crop tested, 11 isolates showed to be non plant pathogenic and to have activity as biological agents against $X$. oryzae pv. oryzae pathotype III, IV and VIII. Further characterization of 11 isolates resulted in 2 isolates that showrd ability to produce chitinase (isolates T5-1118 and R7-1018), phosphatase (isolates T5-1105 and T6-1109), and siderophores (isolates T5-1118 and T61109). The test of bioactive compound effectiveness of 4 isolates to the growth of $X$. oryzae pv. oryzae showed thatT5-1118, T5-1105, T6-1109 and R7-1018 have ability to inhibit X. oryzae pv. oryzae at 48 hours after inoculation of $66,61 \%, 62,4 \%$, $23,97 \%$ and $12,40 \%$, respectively. Identification of 4 bacterial biocontrol isolates with partial sequencing of 16S rRNA gene showed that those bacteria are close to Bacillus nealsonii strain F22 (R7-1018), Chromobacterium sp. MWU328 (T5-1118), Streptomyces sp. Antag 1 (T5-1105) and Kitasatospora nipponensis strains H2-4 (T6-1109).
\end{abstract}

Key words: Bacillus, characterization, Chromobacterium, Kitasatospora, Streptomyces

\section{ABSTRAK}

Eksplorasi dan uji senyawa bioaktif bakteri agensia hayati untuk pengendalian penyakit kresek pada padi. Penelitian ini bertujuan untuk memperoleh isolat bakteri yang berpotensi sebagai agensia hayati untuk menghambat pertumbuhan $X$. oryzae pv. oryzae, menguji keefektifan senyawa bioaktif yang dihasilkannya dan mengidentifikasi isolat bakteri yang teruji berpotensi sebagai agensia hayati tersebut. Metode penelitian meliputi isolasi, penapisan melalui uji antibiosis dan patogenisitas, karakterisasi dengan uji produksi enzim kitinolitik, siderofor dan pelarutan fosfat. Isolat yang terpilih diuji potensi senyawa bioaktifnya dan identifikasi secara molekuler melalui sekuensing gen 16S rRNA. Sebanyak 156 isolat bakteri telah diperoleh dari pertanaman padi, 11 isolat bakteri diantaranya menunjukkan potensi sebagai agensia hayati yang ditunjukkan dengan kemampuan menghambat $X$. oryzae pv. oryzae patotipe III, IV dan VIII dan tidak bersifat patogenik terhadap tanaman. Karakterisasi terhadap11 isolat tersebut menghasilkan 4 isolat yang memiliki keunggulan berupa kemampuan aktivitas kitinolitik (T5-1118 dan R7-1018), melarutkan fosfat ( T5-1105 dan T6-1109), dan produksi siderofor (T5-1118 dan T6-1109). Pengujian potensi senyawa bioaktif dari keempat isolat secara in vitro menunjukkan bahwa isolat T5-1118, T5-1105, T6-1109 dan R7-1018 dapat menghambat pertumbuhan $X$. oryzae pv. oryzae pada 48 jam setelah inokulasi masing-masing sebesar 66,61; 62,4; 23,97 dan $12,40 \%$. Identifikasi berdasarkan sekuensing parsial gen pengkode $16 \mathrm{~S}$ rRNA menunjukkan bahwa keempat isolat tersebut adalah Bacillus nealsonii strain F22 (R7-1018), Chromobacterium sp. MWU328 (T5-1118), Streptomyces sp. Antag1 (T51105) dan Kitasatospora nipponensis strain H2-4 (T6-1109).

Kata kunci: Bacillus, Chromobacterium, karakterisasi, Kitasatospora, Streptomyces

\section{PENDAHULUAN}

Pemerintah Republik Indonesia menargetkan produksi padi tahun 2013 sebesar 72,06 juta ton gabah kering giling (GKG) dan surplus beras 10 juta ton pada tahun 2015. Namun, produksi padi yang dicapai tahun 2013 adalah 71,23 juta ton GKG dengan realisasi luas panen 13,84 juta ha (BPS, 2014). Fakta tersebut 
menunjukkan terdapat kesenjangan antara target dan realisasi produksi padi. Salah satu faktor pembatas dalam produksi padi di Indonesia adalah adanya penyakit kresek atau hawar daun bakteri yang disebabkan oleh Xanthomonas oryzae pv. oryzae. Penyakit ini dapat menyebabkan kehilangan hasil sebesar 35,8\% (Suparyono \& Sudir, 1992). Bakteri patogen ini dilaporkan memiliki beberapa patotipe dan yang dominan di Indonesia adalah patotipe III, IV dan VIII (Suparyono et al., 2004).

Sejauh ini pengendalian penyakit kresek adalah menggunakan varietas unggul baru (VUB) tahan kresek seperti Conde dan Angke. Namun demikian, penggunaan benih VUB ini memiliki beberapa kelemahan diantaranya benih sulit diperoleh di pasaran dan kurang diminati oleh petani maupun konsumen. Selain itu, kelemahan lainnya dalam penggunaan varietas tahan adalah ketahanan terhadap suatu patotipe $X$. oryzae pv. oryzae mudah dipatahkan jika ditanam dalam pola tanam monokultur yang luas dan dalam waktu yang lama. Teknik pengendalian lainnya adalah dengan penggunaan bakterisida sintetik yang memiliki keefektifan yang tinggi dalam mengendalikan bakteri patogen ini, namun penggunaan bakterisida secara terus menerus dapat memicu terjadinya resistensi patogen, matinya organisme bukan sasaran, pencemaran lingkungan, residu pada produk yang membahayakan bagi kesehatan manusia.

Penggunaan agensia hayati sebagai komponen pengendalian dalam mengendalikan X.oryzae pv. oryzae memiliki prospek yang baik karena diyakini bersifat efektif, kompatibel atau sinergi dengan teknik pengendalian lain dan aman bagi lingkungan. Penelitianpenelitian tentang pengembangan agensia hayati terhadap penyakit kresek pada padi telah banyak dilaporkan. Velusamy et al. (2006) berhasil mengisolasi Pseudomonas flourescens yang menghasilkan senyawa anti mikroba yang dikenal sebagai 2,4-diacetyl phloroglucinol (DAPG). Selanjutnya, Hoa et al. (2012) melakukan skrining agensia antagonis dan memperoleh beberapa strain Actinomycetes termasuk Streptomyces virginiae yang mampu menghambat 10 patotipe $X$. oryzae pv. oryzae. Hastuti et al. (2012) melaporkan bahwa Streptomyces spp. dapat menurunkan keparahan penyakit kresek dalam percobaan di rumah kaca maupun di lapangan yang setara dengan perlakuan bakterisida. Demikian pula penggunaan bakteri agensia hayati Pseudomonas diminuta, P. aeruginusa dan Bacillus subtilis dapat mengendalikan bakteri penyebab penyakit kresek ini dan meningkatkan pertumbuhan tanaman padi (Agustiansyah et al., 2013).

Tujuan penelitian ini adalah untuk memperoleh isolat bakteri agensia hayati dari pertanaman padi yang berpotensi menghambat pertumbuhan bakteri penyebab penyakit kresek $X$. oryzae pv. oryzae patotipe III, IV dan VIII, menguji keefektifan senyawa bioaktif yang dihasilkannya dan mengidentifikasi isolat bakteri penghasil senyawa bioaktif yang mampu menghambat pertumbuhan bakteri patogen tersebut.

\section{METODE PENELITIAN}

Tempat dan Waktu. Penelitian dilakukan di Laboratorium Bakteri Patogen Tumbuhan, Departemen Proteksi Tanaman, Institut Pertanian Bogor dari bulan April sampai dengan Desember 2013.

Isolasi Bakteri Agensia Hayati dari Tanah, Rizosfer dan Bakteri Endofit. Contoh tanaman adalah tanaman padi sehat yang diambil di antara tanaman yang terserang penyakit kresek. Lokasi pengambilan contoh dari lahan sawah tadah hujan dilakukan di Desa Widodomartani, Kecamatan Ngemplak dan Desa Harjobinangun, Kecamatan Tratas, Kabupaten Sleman, Yogyakarta (Contoh 1-6), contoh dari lahan sawah irigasi di Desa Gempol Sari, Kecamatan Patok Beusi, Kabupaten Subang, Jawa Barat (Contoh 7), dan contoh dari lahan rawa tipe A di Desa Karang Indah, Kecamatan Mandastana, Kabupaten Barito Kuala, Kalimantan Selatan pada agroekosistem lahan rawa tipe A (Contoh 8).

Isolasi Bakteri dari Tanah dan Rizosfer Pertanaman Padi. Bakteri kandidat agensia hayati diisolasi dari rizosfer tanaman padi dengan metode pengenceran bertingkat dan pencawanan (serial dilution and plating). Sebanyak $10 \mathrm{~g}$ tanah dimasukkan ke dalam $90 \mathrm{ml}$ larutan fisiologis $(0,85 \% \mathrm{NaCl})$ dan dibuat seri pengenceran $10^{0}-10^{-6}$. Suspensi tersebut dihomogenisasikan dalam rotary shaker pada kecepatan 150 rpm selama 30 menit. Suspensi diambil sebanyak $0,1 \mathrm{ml}$ dan disebar pada medium tryptic soy agar/TSA (pancreatic digest of casein $17 \mathrm{~g}, \mathrm{NaCl} 5 \mathrm{~g}$, papaic digest of soybean meal $3 \mathrm{~g}, \mathrm{~K}_{2} \mathrm{HPO}_{4} 2,5 \mathrm{~g}$, glukosa $2,5 \mathrm{~g}$ dan agar $15 \mathrm{~g}$ dalam $1000 \mathrm{ml}$ akuades) $100 \%$ dan $5 \%$, King's B (pepton protease $20 \mathrm{~g}, \mathrm{~K}_{2} \mathrm{HPO}_{4} 1,5 \mathrm{~g}$, $\mathrm{MgSO}_{4} \cdot 7 \mathrm{H}_{2} \mathrm{O} 1,5 \mathrm{~g}$, agar $15 \mathrm{~g}$ dan gliserol $15 \mathrm{ml}$ dalam $1000 \mathrm{ml}$ akuades), water-yeast extract-agar/WYE (yeast extract $0,25 \mathrm{~g}, \mathrm{~K}_{2} \mathrm{HPO}_{4} 0,5 \mathrm{~g}$ dan agar $18 \mathrm{~g}$, dalam $1000 \mathrm{ml}$ akuades), casamino acid-yeast extractglocose-agar/YCED (yeast extract 0,3 g, casamino acid $0,3 \mathrm{~g}, D$-glucose $0,3 \mathrm{~g}, \mathrm{~K}_{2} \mathrm{HPO}_{4} 2 \mathrm{~g}$, dan agar 18 $\mathrm{g}$ dalam $1000 \mathrm{ml}$ akuades) dan nutrient agar/NA (Beef extract $3 \mathrm{~g}$, pepton $5 \mathrm{~g}$ dan agar $15 \mathrm{~g}$ dalam $1000 \mathrm{ml}$ 
akuades), selanjutnya diinkubasikan selama 2-14 hari pada suhu kamar.

Isolasi Bakteri Endofit Tanaman Padi. Isolasi bakteri endofit pada bagian akar, batang dan daun padi mengikuti metode Hallmann et al. (1997) dan Munif et al. (2012).

Penyediaan Isolat Bakteri $X$. oryzae pv. oryzae. Isolat $X$. oryzae pv. oryzae patotipe III, IV dan VIII diperoleh dari koleksi Balai Besar Penelitian Tanaman Padi di Sukamandi, Subang, Jawa Barat. Isolat diremajakan dalam media Wakimoto Agar (WA) (bacto pepton $7 \mathrm{~g}$, sukrosa $17 \mathrm{~g}, \mathrm{Ca}\left(\mathrm{NO}_{3}\right)_{2} \cdot 4 \mathrm{H}_{2} 00,5 \mathrm{~g}$, $\mathrm{Na}_{2} \mathrm{HPO}_{4} \cdot 6 \mathrm{H}_{2} \mathrm{O} 0,5 \mathrm{~g}$, agar $18 \mathrm{~g}$, kaldu dari kentang $300 \mathrm{~g}$ dalam $1000 \mathrm{ml}$ akuades) sebelum digunakan untuk pengujian.

Uji Kemampuan Antibiosis. Seleksi bakteri kandidat agensia hayati melalui pengujian antibiosis terhadap $X$. oryzae pv. oryzae patotipe III, IV dan VIII. Pengujian yang digunakan adalah dengan menggunakan metode double layer (Lisboa et al., 2006) dan cross crossstreak (Madigan et al., 1997) yang telah dimodifikasi.

Metode Double Layer. Isolat bakteri dibiakkan dalam media NB (Nutrient Broth) selama 48 jam di atas inkubator bergoyang (100 rpm). Selanjutnya, suspensi bakteri dengan kerapatan $10^{6}-10^{9} \mathrm{cfu} / \mathrm{ml}$ $\left(\mathrm{OD}_{600}=0,16-1,2\right)$ digunakan dalam pengujian. Bakteri $X$. oryzae pv. oryzae dibiakkan pada media Wakimoto Broth 48 jam di atas inkubator bergoyang (100 rpm). Sebanyak $100 \mu \mathrm{l}$ suspensi $X$. oryzae pv. oryzae disebarkan pada permukaan media WA secara merata menggunakan glass beads dan dikeringanginkan. Selanjutnya, 5 potongan kertas steril dengan diameter 5 $\mathrm{mm}$ diletakan secara teratur pada permukaan media. Sebanyak 4 potongan kertas saring masing-masing ditetesi $5 \mu 1$ suspensi isolat bakteri yang berbeda dan 1 potongan kertas saring ditetesi $5 \mu \mathrm{l}$ media biakan yang tidak mengandung bakteri sebagai kontrol. Pengamatan dilakukan terhadap lebar zone bening di sekitar kertas saring yang merupakan reaksi penghambatan dari bakteri agensia hayati terhadap $X$. oryzae pv. oryzae.

Metode Cross-Streak. Metode ini digunakan untuk pengujian kelompok bakteri aktinomiset pada media WA. Isolat aktinomiset digores pada satu sisi cawan seluas sepertiga cawan. Aktinomiset diinkubasi selama 5 hari untuk memberi kesempatan tumbuh dan menghasilkan senyawa bioaktif yang akan berdifusi ke media agar. Setelah 5 hari, bakteri $X$. oryzae pv. oryzae digoreskan pada sisi cawan yang kosong sepanjang 4,5 $\mathrm{cm}$ dengan arah tegak lurus terhadap goresan isolat aktinomiset dan diinkubasi hingga tumbuh. Isolat aktinomiset yang berpotensi antagonis akan ditunjukkan dengan terbentuknya zona hambatan di mana $X$. oryzae pv. oryzae yang digores tidak tumbuh.

Karakterisasi Bakteri Agens Hayati. Karakterisasi bakteri agens hayati terdiri dari pengujian reaksi hipersensitif, aktivitas kitinolitik, pelarutan posfat dan produksi siderofor.

Pengujian Reaksi Hipersensitif. Bakteri kandidat agensia hayati yang menghasilkan senyawa bioaktif, diuji potensi patogenisitasnya dengan menggunakan uji hipersensitif pada tembakau varietas White Burley. Bakteri yang telah dikulturkan dalam media NB selama 24 jam di atas inkubator bergoyang dengan kecepatan $100 \mathrm{rpm}$ pada kerapatan $10^{8}-10^{9} \mathrm{cfu} /$ $\mathrm{ml}\left(\mathrm{OD}_{600}=0,16-1,2\right)$ kemudian diinfiltrasikan menggunakan jarum suntik (syringe) ke dalam jaringan daun tembakau pada permukaan bawah daun. Respon tanaman berupa gejala hipersenstif diamati pada 1-2 hari setelah inokulasi.

Uji Aktivitas Kitinolitik. Pengujian dilakukan pada media agar koloidal kitin $0,2 \%$ (Lingappa \& Lockwood, 1962). Pengujian aktivitas kitinolitik dilakukan dengan meneteskan suspensi bakteri pada kertas saring sebanyak $5 \mu \mathrm{l}$ di atas media koloidal kitin dan diinkubasikan selama 4-7 hari pada suhu ruangan. Aktivitas kitinolitik ditunjukkan dengan adanya zona bening disekitar biakan bakteri.

Uji Produksi Siderofor. Produksi siderofor dari bakteri agensia hayati dideteksi menggunakan media Chroma Azurol Sulfonate (CAS) agar (Gross, 1990). Suspensi bakteri sebanyak $5 \mu$ l diteteskan pada kertas saring di atas media CAS dan diinkubasikan selama 4-7 hari pada suhu ruangan. Produksi siderofor diindikasikan dengan adanya warna orange di sekeliling koloni bakteri.

Uji Pelarutan Fosfat. Kemampuan bakteri dalam melarutkan fosfat diuji dengan menggunakan media Pikovskaya Agar (Rao \& Sinha, 1962). Suspensi bakteri sebanyak $5 \mu$ l diteteskan pada kertas saring di atas media Pikovskaya dan diinkubasikan selama 4-7 hari pada suhu ruangan. Kemampuan bakteri dalam melarutkan fosfat diindikasikan dengan adanya zona bening di sekeliling koloni bakteri.

Uji Potensi Senyawa Bioaktif untuk Menekan Pertumbuhan $X$. oryzae pv. oryzae. Potensi senyawa bioaktif bakteri agensia hayati dilakukan dengan menggunakan metode peracunan media (poisoned food technique) berdasarkan metode Singh et al. (2005) yang dimodifikasi. Bakteri agensia hayati dibiakkan pada media NB, selama 5 hari untuk kelompok bakteri aktinomiset dan 2 hari untuk kelompok 
bakteri lainnya pada inkubator bergoyang $100 \mathrm{rpm}$. Selanjutnya bahan bioaktif yang dihasilkan bakteri tersebut dipisahkan menggunakan filter (Corning NY 14831 Germany) ukuran 0,45 $\mu 1$. Media LB (Tryptone $10 \mathrm{~g}, \mathrm{NaCl} 5 \mathrm{~g}$, yeast extract $5 \mathrm{~g}$, akuades $1000 \mathrm{ml}$ ) sebanyak $90 \mathrm{ml}$ disiapkan untuk masing-masing perlakuan isolat bakteri dan dicampur dengan senyawa bioaktif sebanyak $10 \mathrm{ml}$. Suspensi $X$. oryzae pv. oryzae patotipe IV sebanyak $100 \mu 1$ yang telah dibiakkan pada media Wakimoto cair selama 24 jam $\left(\mathrm{OD}_{600} 0,610\right)$ diinokulasikan pada media yang mengandung senyawa bioaktif selanjutnya diinkubasikan pada inkubator bergoyang dan diamati secara berkala nilai Absorbance $\left(\mathrm{OD}_{600}\right)$ sampai dengan 48 jam. Percobaan ini menggunakan rancangan acak lengkap (RAL) dengan 3 ulangan. Data dianalisis menggunakan Analysis of Variance (ANOVA) dan dilanjutkan dengan uji Duncan pada taraf nyata 5\%, menggunakan piranti lunak Statistical Analysis System (SAS) versi 9.1.3 untuk Windows.

Identifikasi Isolat Bakteri dengan Sekuensing Parsial Gen Pengkode 16S rRNA. Identifikasi secara molekuler dilakukan pada isolat bakteri yang mampu menghambat pertumbuhan bakteri dan memiliki karakteristik unggul (kemampuan kitinolitik, melarutkan fosfat atau memproduksi siderofor). Persiapan yang dilakukan sebelum melakukan proses sekuensing, terlebih dahulu dilakukan ekstraksi DNA yang mengacu pada protokol kit ekstraksi DNA (Gene JET Genomic DNA Purification Kit \# K0722), selanjutnya amplifikasi gen 16S rRNA dengan Polymerase Chain Reaction (PCR) dan dilanjutkan dengan sekuensing. Data sekuen gen 16S-rRNA yang diperoleh kemudian dimasukkan dalam program BLASTN untuk dianalisis tingkat homologi atau kemiripannya dengan sekuen gen bakteri lain yang ada pada data base.

Amplifikasi DNA kromosom bakteri dilakukan dengan menggunakan sepasang primer general untuk kelompok prokariotik (bakteri), yaitu 27F (5'-AGA GTT TGA TCC TGG CTC AG-3') dan 1492R (5'-GGT TAC CTT ACG ACT T-3') (Lane, 1991). Reaksi PCR dilakukan pada volume total $50 \mu 1$ (Dream Taq GreenPCR Master Mix 2X1(Fermentas) $25 \mu$, Primer 27 F 20 pmol, Primer 149220 pmol, ddH ${ }_{2} \mathrm{O} 17 \mu \mathrm{l}$, template 4-6 $\mu$ l konsentrasi DNA 0,45-21,44 ng/ $\mu \mathrm{l}$ ). Proses PCR (menggunakan mesin Gene Amp PCR System 9700) terdiri dari 35 siklus dengan pemanasan awal pada suhu $95^{\circ} \mathrm{C}$ selama 5 menit, denaturasi pada suhu $95^{\circ} \mathrm{C}$ selama 1 menit, kemudian annealing pada suhu $55^{\circ} \mathrm{C}$ selama 1 menit, ekstensi pada suhu $72^{\circ} \mathrm{C}$ selama 1 menit dan ekstensi akhir pada suhu $72^{\circ} \mathrm{C}$ selama 10 menit. DNA hasil PCR kemudian dielektroforesis gel agarose $1 \%$ dalam $2 \mathrm{X}$ TAE buffer, pada 75 volt selama 35 menit. Hasil elektroforesis divisualisasi pada transiluminator ultraviolet untuk mengamati pita DNA yang terbentuk.

\section{HASIL DAN PEMBAHASAN}

Isolasi Bakteri Kandidat Agensia Hayati. Hasil isolasi bakteri dari bagian tanah, rizosfer dan endofit akar, batang dan daun padi pada penelitian ini diperoleh 1145 isolat. Dari sejumlah isolat tersebut dipilih 156 isolat yang memiliki karakteristik koloni bakteri yang menunjukkan kelompok bakteri yang berpotensi sebagai agensia hayati seperti aktinomiset, Pseudomonas kelompok flourescens, Bacillus dan Chromobacter. Selanjutnya, pengujian aktivitas antibiosis dilakukan pada 156 isolat bakteri tersebut terhadap $X$. oryzae pv. oryzae patotipe III, IV dan VIII. Hasil pengujian antibiosis ditunjukkan oleh terbentuknya zona bening antara bakteri agensia hayati dengan $X$. oryzae pv. oryzae (Gambar 1) dan terdapat keragaman kemampuan dari masingmasing bakteri dalam membentuk zona bening (Tabel 1). Pengujian lebih lanjut diperoleh 11 isolat bakteri yang dapat menekan $X$. oryzae pv. oryzae patotipe III, IV
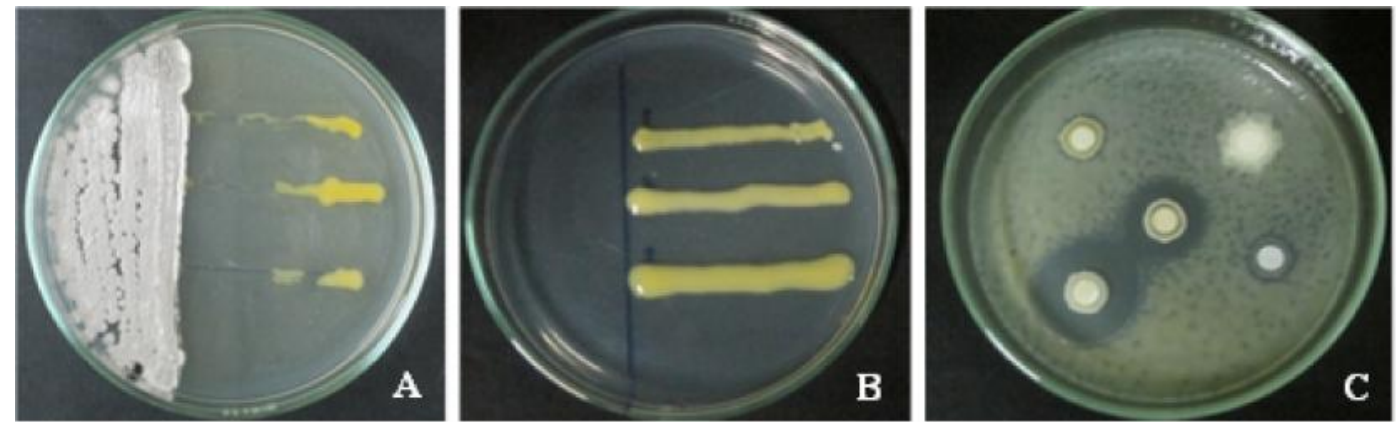

Gambar 1. Uji antibiosis dengan menggunakan metode cross-streak. (A) isolat T5-1105, (B) kontrol, (C) uji antibiosis dengan metode double layer 
dan VIII dan tidak memiliki potensi sebagai patogen tumbuhan (Tabel 1).

Uji Kemampuan Antibiosis. Isolasi agensia hayati pada pertanaman padi telah banyak dilakukan, diantaranya adalah isolasi bakteri endofit dari padi gogo yang memiliki potensi antibiosis terhadap Rhizoctonia solani dan Pyricularia grisea dan dapat memacu pertumbuhan tanaman padi (Munif et al., 2012). Selanjutnya, Santosa et al. (2003), berhasil mengisolasi bakteri yang berasal dari filosfer padi IR64 yang memiliki potensi sebagai agensia pemacu pertumbuhan. Adapun isolasi agensia hayati dari kelompok cendawan endofit telah dilakukan oleh Suada et al. (2012) yang dapat menghambat pertumbuhan $P$. oryzae.

Patogenesitas. Pengujian reaksi hipersensitif (hypersensitive response/HR) pada tanaman tembakau dilakukan untuk mengetahui apakah suatu isolat bakteri bersifat patogenik atau tidak. Jika suatu isolat diinfiltrasikan pada daun tembakau dan menunjukkan gejala nekrosis dalam waktu 24 jam, maka isolat tersebut memiliki potensi patogenik. Nekrosis tidak terjadi pada bakteri yang tidak memiliki potensi patogenik. Kematian sel yang cepat di dalam dan di sekitar sel yang terinfeksi oleh patogen merupakan reaksi hipersensitif dan hal ini berasosiasi dengan respon ketahanan tanaman (Garcion et al., 2007).

\section{Karakteristik Bakteri Agensia Hayati.} Karakterisasi lebih lanjut 11 isolat bakteri agensia hayati meliputi pengujian aktivitas kitinolitik, pelarutan fosfat dan produksi siderofor. Dari hasil pengujian tersebut diperoleh empat isolat bakteri yang berpotensi memiliki salah satu atau lebih karakteristik unggulan (aktivitas kitinolitik, pelarutan fosfat dan produksi siderofor) sebagai agensia hayati (Tabel 2).

Aktivitas kitinolitik dimiliki oleh mikroba yang menghasilkan ezim kitinase. Enzim ini salah satu yang berperan penting dalam mekanisme antibiosis yaitu menghancurkan dinding sel beberapa cendawan patogen seperti Sclerotium rolfsii, Fusarium oxysporum (Pal \& Gardener, 2006) dan Rhizoctonia solani (Wahyudi et al., 2011). Bakteri kitinolotik telah banyak diketahui berasal dari kelompok Bacillus, Serratia (Pal \& Gardener, 2006), Aeromonas, Enterobacter, Paenibacillus, Streptomyces dan Chromobacterium (Park et al., 2005).

Adapun aktivitas pelarutan fosfat dan produksi siderofor merupakan mekanisme kompetisi nutrisi yang dilakukan oleh agensia hayati dengan patogen. Fosfat di dalam tanah seringkali berada dalam bentuk yang terikat dengan kalsium pada tanah basa, sedangkan pada tanah masam terikat dengan aluminum dan besi. Bakteri pelarut fosfat seperti Bacillus, Pseudomonas dan Rhizobium dapat meningkatkan ketersediaan fosfat di dalam tanah (Goldstein, 1995) bagi tanaman dan mikroba tanah lainnya. Hal ini berkaitan dengan dihasilkannya asam organik seperti formic, acetic, propionic, lactic, glycolic, fumaric dan succinic yang dapat meningkatkan $\mathrm{pH}$ tanah dan menghasilkan $\mathrm{H}^{+}$dengan menggantikan $\mathrm{Ca}^{2+}$ kemudian melepaskan $\mathrm{HPO}_{4}{ }^{2-}$ ke dalam tanah (Yasmin et al., 2009).

Demikian pula dengan ketersediaan besi yang dapat diserap oleh organisme sangat rendah yaitu sekitar

Tabel 1. Hasil pengujian kemampuan antibiosis dan reaksi hipersensitif bakteri agensia hayati

\begin{tabular}{lccclll}
\hline & \multicolumn{3}{c}{ Zona hambat $(\mathrm{mm})$} & \multicolumn{2}{c}{ Asal isolat } \\
\cline { 2 - 4 } Kode isolat & \multicolumn{2}{c}{ Patotipe X. oryzae pv. oryzae } & Habitat & Kabupaten & Agroekosistem \\
\cline { 2 - 4 } & III & IV & VIII & & & \\
\hline T5-1118 & 3 & 5 & 3 & Tanah & Sleman & Sawah tadah hujan \\
R7-1018 & 3 & 3 & 2 & Rhizosfer & Subang & Sawah irigasi \\
EA4-1130 & 7 & 4 & 2 & Endofit akar & Sleman & Sawah tadah hujan \\
R7-1024 & 2 & 3 & 2 & Rhizosfer & Subang & Sawah Irigasi \\
T6-1112* & 30 & 25 & 34 & Tanah & Sleman & Sawah tadah hujan \\
EA8-910 & 2 & 5 & 5 & Endofit akar & Barito Kuala & Rawa \\
T6-1109* & 45 & 40 & 39 & Tanah & Sleman & Sawah tadah hujan \\
R1-1095* & 14 & 24 & 28 & Rhizosfer & Sleman & Sawah tadah hujan \\
T5-1105* & 33 & 23 & 25 & Tanah & Sleman & Sawah tadah hujan \\
EB7-1032 & 3 & 5 & 2 & Endofit batang & Subang & Sawah irigasi \\
R7-1013 & 3 & 8 & 6 & Rhizosfer & Subang & Sawah irigasi \\
\hline
\end{tabular}


$10^{-18} \mathrm{M}$. Hal ini tidak mencukupi kebutuhan mikroba untuk mendukung pertumbuhannya yang secara umum dibutuhkan konsentrasi $10^{-6} \mathrm{M}$. Untuk bertahan, beberapa mikroba mampu menghasilkan siderofor yaitu senyawa yang dapat mengikat besi (iron-binding ligands) (Pal \& Gardener, 2006). Pseudomonas fluorescens memproduksi pseudobactins yaitu molekul kompleks pengikat besi yang dapat menekan perkembangan penyakit dari kelompok cendawan Oomycetes (Handelsman \& Stabb, 1996).

Karakteristik morfologi keempat bakteri agensia hayati memiliki keragaman warna, bentuk dan elevasi koloni bakteri (Gambar 2). Isolat T5-1105 dan T6-1109 menunjukkan karakteristik kelompok bakteri aktinomiset yaitu terdapat miselium udara (aerial) dan memiliki massa spora yang berwarna (Taechowisan et al., 2003). Isolat T5-1105 memiliki spora, koloni berwarna putih, pinggiran rata, elevasi datar, kering, tekstur lebih lembut dibandingkan dengan isolat T6-1109, dan memiliki bau khas tanah. Isolat T6-1109 menghasilkan spora, memiliki koloni berwarna putih dan menjadi abu-abu jika umur koloni sudah tua, pinggiran bergerigi, elevasi cembung, kering, tekstur agak keras dan memiliki bau khas tanah. Adapun karakteristik morfologi isolat T5-1118 adalah koloni berwarna ungu, pinggiran rata, elevasi cembung, basah dan tekstur lembut. Warna ungu yang tidak berdifusi pada media agar menunjukkan karakteristik kelompok bakteri Chromobacterium (Leifson, 1956). Isolat R7-1018 memiliki koloni berwarna putih, pinggiran bergerigi, elevasi datar, basah dan tekstur lembut.

\section{Potensi Senyawa Bioaktif dalam Menekan} Pertumbuhan $X$. oryzae pv. oryzae. Mekanisme agensia hayati dalam menghambat pertumbuhan patogen dan perkembangan penyakit dapat secara langsung melalui hiperparasit atau antibiosis dan tidak langsung melalui kompetisi dan induksi ketahanan tanaman. Mekanisme antibiosis yaitu dengan dihasilkannya senyawa bioaktif seperti antibiotik, enzim pendegradasi dan senyawa lainnya seperti ammonia, karbon dioksida

Tabel 2. Hasil pengujian aktivitas kitinolitik, pelarutan fosfat dan produksi siderofor bakteri agensia hayati

\begin{tabular}{lccc}
\hline \multirow{2}{*}{ Kode isolat } & \multicolumn{3}{c}{ Zona reaksi (mm) } \\
\cline { 2 - 5 } & Kitinolitik & Pelarut Fosfat & Siderofor \\
\hline T5-1118 & 5 & - & 2 \\
R7-1018 & 3 & - & - \\
EA4-1130 & - & - & - \\
R7-1024 & - & - & - \\
T6-1112 & - & - & - \\
EA8-910 & - & - & - \\
T6-1109 & - & 2 & 1,5 \\
R1-1095 & - & - & - \\
T5-1105 & - & 2 & - \\
EB7-1032 & - & - & - \\
R7-1013 & - & - & - \\
\hline
\end{tabular}
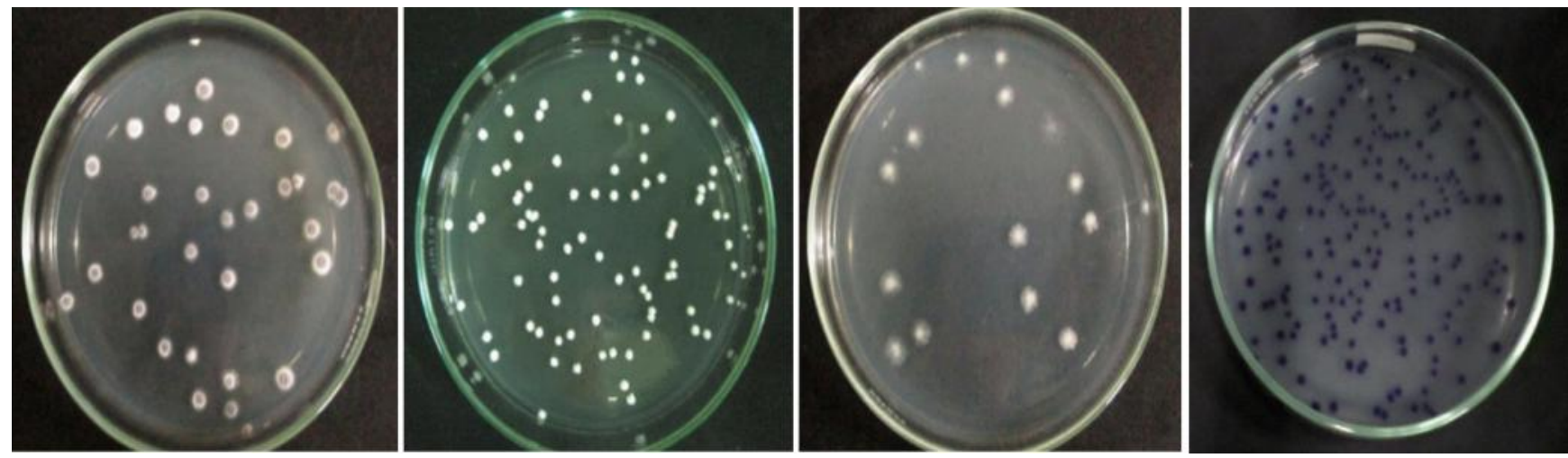

Gambar 2. Karakteristik koloni beberapa isolat bakteri agens hayati. (A) T6-1109; (B) T5-1105; (C) R7-1018; (D) T5-1118 
dan hidrogen sianida yang dapat membunuh atau menghambat pertumbuhan mikroorganisme lain $(\mathrm{Pal} \&$ Gardener, 2006). Antibiotik dapat menghambat sintesa dinding sel, sintesa protein, sintesa DNA/RNA dan sintesa koenzim folat (Walsh, 2003). Selain itu, senyawa antibiotik dapat berperan sebagai agensia penginduksi (elicitor) ketahanan tanaman terhadap penyakit (Lyon, 2007).

Pengujian senyawa bioaktif dilakukan pada empat isolat yang memiliki karakteristik unggulan. Senyawa bioaktif yang dihasilkan oleh isolat T6-1109, T5-1105, R7-1018 dan isolat T5-1118 menunjukkan potensi menghambat pertumbuhan $X$. oryzae pv. oryzae patotipe IV secara nyata berdasarkan uji Duncan pada taraf kepercayaan 95\% (Gambar 3). Pertumbuhan $X$. oryzae pv. oryzae terendah dihasilkan oleh perlakuan senyawa bioaktif asal isolat T5-1118 dengan keefektifan penekanan sebesar $66,61 \%$. Selanjutnya diikuti berturutturut isolat T5-1105, T6-1109 dan R7-1018 memiliki efektivitas penekanan sebesar 62,4;23,97 dan 12,40\%.

Pertumbuhan $X$. oryzae pv. oryzae dapat dihambat oleh senyawa bioaktif yang dihasilkan oleh ke empat isolat bakteri agensia hayati diduga dapat melalui berbagai mekanisme, diantaranya produksi senyawa antibiotik. Antibiotik kasugamycin yang dihasilkan oleh Streptomyces kasugaensis bersifat bakterisida dan fungisida. Antibiotik ini berperan sebagai penghambat (inhibitor) dalam sintesa protein pada mikroorganisme. Senyawa antibiotik ini telah banyak digunakan untuk mengendalikan penyakit blast pada padi dan beberapa penyakit yang disebabkan oleh bakteri patogen kelompok Pseudomonas (Doumbou et al., 2001). Antibiotik lainnya yang dihasilkan oleh aktinomiset adalah vancomycin, teicoplanin, nocardicin, dan thienamycin dapat menghambat sintesa dinding sel (peptidoglycan), erythromycin, kanamycin dan oleandomycin dapat mengikat ribosom dan rifamycin dapat menghambat sintesa RNA (Walsh, 2003).

Mekanisme senyawa bioaktif dalam menghambat pertumbuhan patogen lainnya adalah produksi enzim pendegradasi senyawa polimerik seperti protein, kitin, selulosa, hemiselulosa dan DNA. Senyawa volatil yang dapat menghambat pertumbuhan mikroba adalah hidrogen sianida (HCN) dan amonia. HCN dapat menghambat proses oksidasi cytochrome dan sangat toksik terhadap mikroorganisme yang bersifat aerob. Salah satu penghasil HCN adalah Pseudomonas fluorescens yang dapat menghambat perkembangan penyakit black root pada tembakau. Adapun amonia adalah senyawa yang bersifat volatil, salah satunya dihasilkan oleh Enterobacter cloacae dapat menekan perkembangan penyakit rebah kecambah pada kapas yang disebabkan oleh Pythium ultimum (Pal \& Gardener, 2006).

\section{Identifikasi Isolat Bakteri dengan Sekuensing Parsial Gen Pengkode 16S rRNA. Keempat isolat} bakteri yang menunjukkan potensi menghambat pertumbuhan $X$. oryzae pv. oryzae berdasarkan uji senyawa bioaktif selanjutnya diidentifikasi secara genotifik untuk memastikan identitas bakteri. Informasi ini diperlukan untuk pengembangan lebih lanjut dari bakteri agensia hayati tersebut. Hasil PCR DNA gen pengkode 16S rRNA keempat isolat selanjutnya dianalisis dengan sekuensing secara parsial. Hasil analisis sekuen menggunakan program BLASTN di pusat data Gen Bank menunjukkan isolat T5-1105 dan T6-1109 dari kelompok bakteri Aktinomiset, isolat T51118 adalah Chromobacterium dan isolat R7-1018 adalah Bacillus (Tabel 3).

Sekuensing 16S rRNA merupakan teknik yang sangat baik dan paling umum digunakan untuk mengidentifikasi bakteri dengan membandingkan seberapa besar persamaan urutan nukleotidanya. Hal ini dikarenakan pada beberapa bagian $16 \mathrm{~S}$ rRNA merupakan gen yang sangat konservatif. Oleh karenanya, penggunaan pasangan primer pada PCR dapat mengenali bagian gen yang konservatif tersebut dan mengamplifikasinya. Produk PCR selanjutnya disekuensing dan diperoleh urutan nukleotidanya kemudian dapat dibandingkan dengan data bakteri yang telah diketahui dan dideterminasi (Dale \& Park, 2010).

Kelompok bakteri aktinomiset telah banyak diketahui sebagai penghasil beberapa senyawa antibiotik seperti polyketides, $\beta$-lactams dan peptida yang berfungsi sebagai anti fungal, anti tumor dan immuno suppresive (Behal, 2000). Genus Kitasatospora merupakan kelompok bakteri aktinomiset yaitu dari famili Streptomycetaceae (Groth et al., 2004).

Hasil identifikasi genotif selanjutnya terhadap isolat T5-1118 (Chromobacterium sp.) dan isolat R71018 (Bacillus nealsonii), dapat menjelaskan bahwa bakteri tersebut dapat menekan pertumbuhan $X$. oryzae pv. oryzae berdasarkan hasil-hasil penelitian sebelumnya. Kim et al. (2014) melaporkan bahwa Chromobacterium sp. strain C61 menghasilkan antibiotik chromobactomycin yang dapat menghambat pertumbuhan beberapa cendawan patogen dan menekan perkembangan beberapa penyakit tumbuhan. Demikian halnya dengan kelompok bakteri Bacillus juga telah banyak diketahui menghasilkan antibiotik seperti, iturin A, surfactins (Beric et al., 2012), bacillomycin D, mycosubtilin dan zwittermicin A (Pal \& Gardener, 2006). 


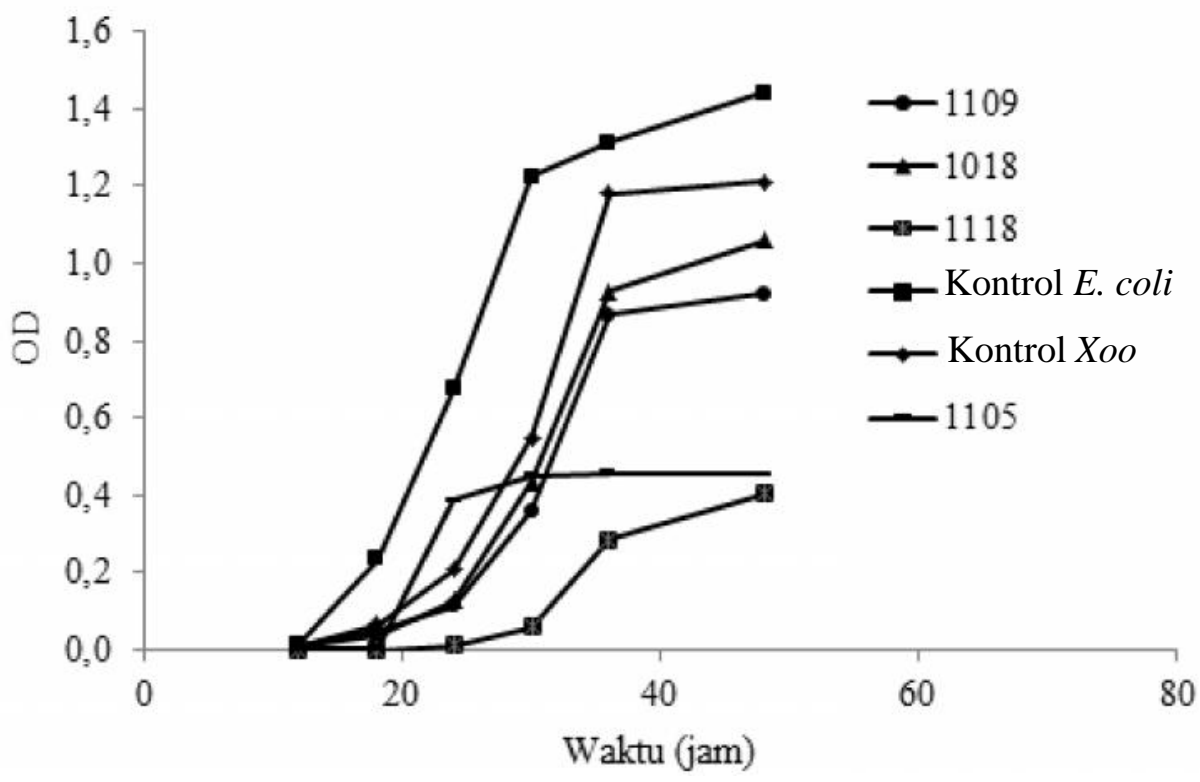

Gambar 3. Pengaruh senyawa bioaktif bakteri agensia hayati terhadap pertumbuhan populasi X. oryzae pv. oryzae patotipe IV. Huruf yang sama menunjukkan tidak berpengaruh nyata secara statistik berdasarkan uji Duncan dengan taraf nyata $5 \%$ terhadap kontrol

Tabel 3. Hasil analisis sekuen parsial gen 16S rRNA isolat bakteri dengan sekuen gen 16S rRNA di pusat data GenBank

\begin{tabular}{clc}
\hline Kode isolat & \multicolumn{1}{c}{ Spesies yang homolog } & Kemiripan (\%) No aksesi \\
\hline T5-1105 & Streptomyces sp. Antag1 & 98 (JQ417268.1) \\
T6-1109 & Kitasatospora nipponensis H2-4 & 94 (HQ857768.1) \\
R7-1018 & Bacillus nealsonii strain F22 & 99 (JQ579625.1) \\
T5-1118 & Chromobacterium sp.MWU328 & 99 (JN653466.1) \\
\hline
\end{tabular}

Berdasarkan potensi senyawa bioaktif yang dihasilkan oleh keempat isolat tersebut maka, isolat ini berpotensi untuk dikembangkan sebagai agensia hayati dalam menekan penyakit kresek yang disebabkan oleh $X$. oryzae pv. oryzae. Namun demikian perlu dilakukan pengujian lanjutan secara inplanta baik di rumah kaca maupun di lapangan untuk menguji keefektifannya dalam mengendalikan penyakit kresek.

\section{SIMPULAN}

Dari seleksi bakteri dari pertanaman padi diperoleh 11 isolat bakteri agensia hayati yang berpotensi dapat menghambat $X$. oryzae pv. oryzae patotipe III, IV dan VIII dan tidak bersifat patogenik terhadap tanaman. Karakterisasi terhadap 11 isolat tersebut menunjukkan bahwa isolat-isolat tersebut memiliki kemampuan kitinolitik (isolat T5-1118 dan R7-1018), melarutkan fosfat (T5-1105 dan T6-1109), dan memproduksi siderofor (isolat T5-1118 dan T6-1109). Pengujian senyawa bioaktif dari masing-masing 4 isolat tersebut terhadap pertumbuhan $X$. oryzae pv. oryzae secara in vitro menunjukkan bahwa isolat T5-1118, T51105, T6-1109 dan R7-1018 dapat menghambat pertumbuhan $X$. oryzae pv. oryzae pada 48 jam setelah inokulasi masing-masing sebesar 66,$61 ; 62,4 ; 23,97$ dan $12,40 \%$. Selanjutnya hasil identifikasi dengan sekuensing parsial gen pengkode $16 \mathrm{~S}$ rRNA terhadap keempat isolat tersebut adalah Chromobacterium sp. MWU328 (T51118), Streptomyces sp. Antag 1 (T5-1105), Kitasatospora nipponensis strain H2-4 (T6-1109) dan Bacillus nealsonii strain F22 (R7-1018).

\section{SANWACANA}

Penelitian ini merupakan salah satu bagian dari hasil penelitian KKP3N 2013 kerjasama dengan Badan Penelitian dan Pengembangan Pertanian, Kementrian 
Pertanian RI dengan judul: “Aplikasi Teknik Metagenom dalam Eksplorasi Agens Hayati dan Induksi Resistensi terhadap Penyakit Kresek yang Disebabkan oleh Xanthomonas oryzae pv. oryzae pada Tanaman Padi”, No. Kontrak : 691/LB.620/I.1/2/2013 tanggal 25 Februari 2013.

\section{DAFTAR PUSTAKA}

Agustiansyah, Ilyas S, Sudarsono, \& Machmud M. 2013. Karakterisasi rizobakteri yang berpotensi mengendalikan bakteri Xanthomonas oryzae pv. oryzae dan meningkatkan pertumbuhan tanaman padi. J. HPT Tropika 13(1): 42-51.

[BPS] Badan Pusat Statistik. 2014. Produksi padi, jagung dan kedelai (angka tetap tahun 2013). Berita Resmi Statistik. 50(7): 1-10.

Behal V. 2000. Bioactive products from Streptomyces. Adv. Appl. Microbiol. 47: 113-156.

Berić T, Kojić M, Stancović S, Topisirović L, Degrassi G, Myers M, Venturi V, \& Fira D. 2012. Antimicrobial activity of Bacillus sp. natural isolates and their potential use in the biocontrol of phytopathogenic bacteria. Food Technol. Biotech. 50(1): 25-31.

Dale JW \& Park SF. 2010. Molecular Genetics of Bacteria. $5^{\text {th }}$ Ed.Wiley-Blackwell, Oxford.

Doumbou CL, Salove MKH, Crawford DL, \& Beaulieu C. 2001. Actinomycetes, promising tools to control plant diseases and promote plant growth. Phytoprotection 82(3): 85-102.

Garcion C, Lamotte O, \& Métraux JP. 2007. Mechanisms of defence to pathogens: biochemistry and physiology. In: Walters D, Newton A, \& Lyon G (Eds.). Induced Resistance for Plant Defense: Sustainable Approach to Crop Protection. pp. 109-132. Blackwell Publishing, Oxford.

Goldstein AH. 1995. Recent progress in understanding the molecular genetics and biochemistry of calcium phosphate solubilization by gram negative bacteria. Biol. Agric. Hort. 12(2): 185-193.

Gross M. 1990. Siderophores and fluorescent pigments. In: Klement Z, Rudolph K, \& Sand DC (Eds.). Methods in Phytobacteriology. pp. 434-438. Budapest, Hungary.
Groth I, Rodriguez C, Schütze B, Schmitz P, Leistner E, \& Goodfellow M. 2004. Five novel Kitasatospora species from soil: Kitasatospora arboriphila sp. nov., $K$. gansuensis sp. nov., $K$. nipponensis sp. nov., $K$. paranensis sp. nov. and K. terrestris sp. nov. Int. J. Syst. Evol. Microbiol. 54: 2121-2129.

Hallmann J, Quadt-Hallmann A, Mahaffee WF, \& Kloepper JW. 1997. Bacterial endophytes in agricultural crops. Can. J. Microbiol. 43(10): 895-914.

Handelsman J \& Stabb EV. 1996. Biocontrol of soilborne plant pathogens. Plant Cell. 8: 1855-1869.

Hastuti RD, Lestari Y, Saraswati R, Suwanto A, \& Chaerani. 2012. Capability of Streptomyces spp. in controlling bacterial leaf blight disease in rice plants. Am. J. Agri. Biol. Sci. 7(2): 217-223.

Hoa PTP, Quang ND, Sakiyama Y, Hop DV, Hang DT, Ha TH, Van NT, Quy NTK, \& Dao NTA. 2012. Screening for Actinomyces isolated from soil with the ability to inhibit Xanthomonas oryzae pv. oryzae causing rice bacterial blight disease in Vietnam. Afr. J. Biotechnol. 11(80): 1458614594.

Kim HJ, Choi HS, Yang SY, Kim IS, Yamaguchi T, Sohng JK, Park SK, Kim JC, Lee CH, Garderner BM, \& Kim YC. 2014. Both extracellular chitinase and new cyclic lipopeptide, chromobactomycin, contribute to the biocontrol activity of Chromobacterium sp. C61. Mol. Plant Pathol.15(2): 122-132.

Lane DJ. 1991. 16S/23S rRNA sequencing. In: Stackebrandt E \& Goodfellow M (Eds.). Nucleic acid Techniques in Bacterial Systematics. pp. 115-175. John Wiley and Sons, Chichester, New York.

Leifson E. 1956. Morphological and physiological characteristics of the genus Chromobacterium. J. Bacteriol. 71(4): 393-400.

Lingappa Y \& Lockwood JL. 1962. Chitin media for selective isolation and culture of actinomycetes. Phytopathology 52: 317-323.

Lisboa MP, Bonatto D, Bizani D, Henriques JAP, \& Brandelli A. 2006. Characterization of a bakteriosin-like substance produced by Bacillus amyloliquefaciens isolated from the Brazilian Atlantic forest. Int. Microbiol. 9: 111-118. 
Lyon G. 2007. Agens that can elicit induced resistance. In: Walters D, Newton A, \& Lyon G (Eds.). Induced Resistance for Plant Defense: Sustainable Approach to Crop Protection. pp. 9-29. Blackwell Publishing, Oxford.

Madigan MT, Martinko JM, \& Parker J. 1997. Brock's Biology of Microorganisms. Ed ke-8. : PrenticeHall, Inc New Jersey.

Munif A, Wiyono S, \& Suwarno. 2012. Isolasi bakteri endofit asal padi gogo dan potensinya sebagai agens biokontrol dan pemacu pertumbuhan. $J$. Fitopatol. Indones. 8(3): 57-64.

Pal KK \& Gardener BM. 2006. Biological control of plant pathogens. The Plant Health Instructor. DOI: 10.1094/PHI-A-2006-1117-02. APSnet 25 p.

Park SK, Lee MC, \& Harman GE. 2005. The biocontrol activity of Chromobacterium sp. strain C-61 against Rhizoctonia solani depends on the productive ability of chitinase. Plant Pathol. $J$. 21(3): 275-282.

Rao SWCB \& Sinha MK. 1962. Phosphate dissolving microorganism in the soil and rhizosphere. Ind. J. Sci. 23: 272-278.

Santosa DA, Handayani N, \& Iswandi A. 2003. Isolasi dan seleksi bakteri filosfer pemicu tumbuh dari daun padi (Oryza sativa L.) varietas IR64. J. Tanah dan Lingkungan 5(1): 7-12.

Singh G, Maurya S, deLampasona MP, \& Catalan C. 2005. Chemical constituents, antimicrobial investigations and antioxidative potentials of Anethumgraveolens L. essential oil and acetone extract part 52. J. Food Sci. 70(4): 208-215.
Suada IK, Suhartini DMWY, Sunariasih NPL, Wirawan IGP, Chun KW, Cha JY, \& Ohga S. 2012. Ability of endophytic fungi isolated from rice to inhibit Pyricularia oryzae-induced rice blast in Indonesia. J. Fac. Agr. 57(1): 51-53.

Suparyono, Sudir, \& Suprihanto. 2004. Pathotype profile of Xanthomonas oryzae pv. oryzae isolates from the rice ecosystem in Java. Indones. J. Agric. Sci. 5(2): 63-69.

Suparyono \& Sudir. 1992. Perkembangan penyakit bakterihawar daun pada stadia tumbuh yang berbeda dan pengaruhnya terhadap hasil padi. Media Penelitian Sukamandi 12: 6-9.

Taechowisan T, Peberdy JF, \& Lumyong S. 2003. Isolation of endophytic actinomycetes from selected plants and their antifungal activity. World J. Microbiol. Biotechnol. 19(4): 381-385.

Velusamy P, Immanuel JE, Gnanamanickam SS, \& Thomashow L. 2006. Biological control of rice bacterial blight by plant-associated bacteria producing 2,4-diacetylphloroglucinol. Can. J. Microbiol. 52: 56-65.

Wahyudi AT, Astuti RI, \& Giyanto. 2011. Screening of Pseudomonas sp. isolated from rhizosphere of soybean plant as plant growth promoter and biocontrol agent. Am. J. Agric. Biol. Sci. 6(1): 134-141.

Walsh C. 2003. Antibiotics: Action, Origins, Resistance. $1^{\text {st }}$ Edition. ASM Press, Washington.

Yasmin F, Othman R, Sijam K, \& Saad MS. 2009. Characterization of beneficial properties of plant growth-promoting rhizobacteria isolated from sweet potato rhizosphere. Afr. J. Microbiol. Res. 3(11): 815-821. 